\title{
Elitist in Façade
}

\section{Chinese Transnationalism Reticulated within Global Capitalism between Canada and China}

\author{
Hongxia Shan \\ University of British Columbia \\ hongxia.shan@ubc.ca
}

\begin{abstract}
Drawing on a qualitative study of a group of professional Chinese women navigating their career lives between China and Canada, this paper addresses how Chinese transnationalism is constituted within global capitalism. It starts by mapping the career lives of the Chinese immigrant women. Their experiences point to the emergence of a transnational field between Canada and China where skill/labor and capital conjoin in distinct ways. The study further shows that this transnational social field is comprised of a complex of social relations reticulated through multiple institutions, organizations, and actors. Although the interest of economic accumulation and Western-centric social and cultural orders are predominant in shaping the women's career spaces, this transnational field also provides conduits for alternative flows of power, privileging the entrepreneurial quest for social, cultural, and economic capitals. Despite its elitist façade, the transnational field is itself also vulnerable, fractured, and prone to crisis.
\end{abstract}

\section{Keywords}

transnationalism - transnational social field - global capitalism - women immigrants Chinese transnationalism - Asian and Pacific area 


\section{Introduction}

The contemporary era of globalization is driven by the pursuit of "flexible accumulation"1 and fuelled by the ideology of neoliberalism, a malleable technology taken up by various governments ${ }^{2}$ that fosters and privileges entrepreneurial subjects. It not only sponsors unfettered mobility of economic capital on the global scale, but progressively calls for unencumbered movement of skilled labor within and across national borders. The latter is exhibited in part in the changing immigration regimes practiced by different nations. In traditional immigrant settlement countries, such as Australia and Canada, where immigration practices were historically dominated by exclusionary mechanisms based on racial discrimination, the last four decades have witnessed the rise of increasingly targeted immigration policies dedicated to attracting skilled immigrants regardless of their country of origin. In traditional countries of emigration, such as China and India, the governments have ratcheted up efforts to appeal to their diaspora elites through proactive migration policies. Given the global competition for talent, skilled and entrepreneurial immigrants have found unprecedented mobility across national borders, making transnationalism an ever more pronounced phenomenon today, which is especially true for Chinese people in the Asia Pacific region.

Researchers have started addressing the phenomenon of transnationalism since the 1990s. ${ }^{3,4}$ It is recognized that transnationalism is closely tied to, if not engendered through, global capitalism. ${ }^{5,6}$ However, in studies of transnationalism, particularly in studies of Chinese transnationalism, global capitalism is often taken as the historical backdrop against which transnational engagements unfold. With few exceptions, ${ }^{7}$ rarely have researchers directly

1 David Harvey, The Condition of Postmodernity (Oxford: Blackwell, 1989).

2 Aihwa Ong, Neoliberalism as Exception: Mutations in Citizenship and Sovereignty (Durham: Duke University Press, 2006).

3 Aihwa Ong, Flexible Citizenship: The Cultural Logics of Transnationality (Durham: Duke University Press, 1999).

4 Nina Glick Schiller, Linda Basch and Cristina Blanc-Szanton, "Transnationalism: A New Analytic Framework for Understanding Migration," Annals of the New York Academy of Sciences 645, no. 1 (1992): 1-24.

5 Steven Vertovec, "Migrant Transnationalism and Modes of Transformation," International Migration Review 38, no. 3 (2004): 970-1001.

6 Lloyd L. Wong, “Globalization and Transnational Migration," International Sociology 12, no. 3 (1997): 329-351.

7 Ong, Flexible Citizenship. 
addressed how globalization - as a process of capitalization enacted by multiple actors ${ }^{8}$ - is constitutive of transnationalism. This paper contributes to the existing scholarship on transnationalism, particularly Chinese transnationalism, with a focus on the production of transnationalism within global capitalism, which enrols multiple institutions, organizations and individuals. Empirically, it draws on a qualitative study that examines the social organization of the career lives of 15 professional Chinese women engaged in circular migration between China and Canada.

Following, I review the literature on Chinese transnationalism. I then introduce and expand the notion of a transnational social field as a conceptual framework to grapple with the social organization of Chinese transnationalism, followed by an introduction of the research, methods, and respondents. When presenting research findings, I first chart the migratory and career trajectories of 15 professional Chinese women, before I map the complex social relations constitutive of the transnational field within which their experiences are embedded. I end the paper with a recap of the findings and a discussion of the significance and implications of the findings.

\section{Chinese Transnationalism}

The Chinese have historically been involved in international migration. Ma and Cartier divide the history of Chinese migration into two historical periods of time. ${ }^{9}$ Prior to 1960s, it was primarily villagers from Guangdong and Fujian provinces in South China who went abroad as labors and traders. After the 1960s, Chinese emigrated mostly from Hong Kong, Taiwan, Southeast Asia, and more recently Mainland China. Recent waves of Chinese immigration are instigated variously by political uncertainties, ethnic discrimination, and in the case of the Chinese from Mainland China, perhaps China's opening up to the world. The major destination countries for Chinese immigrants include traditional settlement countries on the Asian Pacific rim, such as Australia, Canada, and the United States, and some European countries, such as the United Kingdom. Compared with earlier waves of immigration, the Chinese who immigrated in the post-1960 period are comprised of a higher

8 Harvey, The Condition of Postmodernity.

9 Laurence J. C. Ma and Carolyn L. Cartier, The Chinese Diaspora: Space, Place, Mobility, and Identity (Lanham: Rowman \& Littlefield, 2003). 
percentage of well-educated and relatively well-off business people and professionals. ${ }^{10}$

Chinese immigrants have always maintained social, cultural, economic, and political ties with their home countries. ${ }^{11,12}$ It is, however, only in the 1990s that researchers started taking up lenses of transnationalism to shed light on the experiences of Chinese immigrants. In her pioneering work on Chinese immigrant investors, business owners, and professionals in North America and South Asia, Ong links Chinese transnationalism to forms of cultural struggles that privilege male power, gendered familial norms, ethnic order, and national ideologies. ${ }^{13}$ For instance, in Chapter Three, where she examines the experiences of elite Chinese in the United States, she shows that while the immigrants seek to convert economic capital to social capital in their host country, their ability to do so is limited by the ethnic, social, and moral orders prevalent in the local society. In Chapter Four, where she focuses on the experiences of Chinese families shuttling within the Asian Pacific region, Ong pinpoints that as a transnational strategy, the family deploys flexible citizenship, which is subjected to the regimes of family, nation states, and the market place. In Chapter Five that focuses on Chinese capitalism in South Asia, Ong highlights the ethnic and fraternal links and male bonding celebrated by the elite transnational subjects. Meanwhile, she also shows "the dark secrets of family, nation states and global capitalism" that entrap women in the domestic domains or gendered and exploitative workplaces..$^{14}$ She subsequently argues that mobile forces of capitalism are "alternatively destructive and creative of the class, ethnic and gender relations that constitute the very transnational networks that have developed within and alongside global capitalism."15

In Canada, the last twenty years have also witnessed an increasing number of studies of Chinese transnationalism, primarily focusing on two different populations: wealthy business elites, or what Wong calls the "global capitalists," who come to Canada through the business immigration programs, and

\footnotetext{
$10 \quad$ Ma and Cartier, The Chinese Diaspora.

11 Gregor Benton, "Chinese Transnationalism in Britain: A Longer History," Identities: Global Studies in Culture and Power 10, no. 3 (2003): 347-375.

12 Douglas E. Ross, Archaeology of Asian Transnationalism (Gainesville: University Press of Florida, 2013).

13 Ong, Flexible Citizenship.

14 Ong, Flexible Citizenship, 157.

15 Ibid., 157.
} 
skilled immigrants who struggle with under- and un-employment. ${ }^{16}$ Wong's large survey study shows that Chinese business investors and entrepreneurs, as global capitalists, are involved in multiple social fields, including family, personal, social, ethnic, and business fields. In a large immigrant survey, Ley also profiles business immigrants who self-identified as ethnic Chinese. ${ }^{17}$ His study finds some negative association between transnational activities and immigrants' social and cultural integration in Canada. However, Ley challenges the traditional notion of integration and argues that "astronaut households" may see the two shores of the Pacific Ocean, instead of one country, as an integrated region of opportunity. Walter's qualitative study followed two Chinese women from investor families over a period of eight years. It casts doubts on Ong's notion of flexible citizenship, ${ }^{18}$ and by way of extension, perhaps Ley's expanded notion of integration. Walter argues that while being mobile and flexible citizens may be an initial intention for some immigrants, transnationalism might be a transient phenomenon. In the long run, immigrants still need to deal with issues of belonging, integration, and settlement.

Some of the studies within this body of literature focus specifically on the experiences of skilled Chinese immigrants. Salaff and Greve find that given the demands of requalification and the loss of social capital as a result of relocation, dual-career Chinese couples develop coping strategies through mobilizing their transnational social network (i.e., sending children back home to their parents, or bringing parents to support them in Canada).${ }^{19}$ Similarly, Man and Cohen, and Das Gupta et al. examine the transnational strategies professional female immigrants from China and India exercised to meet the contradictory demands at home and in the labor market, while also trying

16 Lloyd L. Wong, "Globalization and Transnational Migration: A Study of Recent Chinese Capitalist Migration from the Asian Pacific to Canada," International Sociology 12, no. 3 (1997): 329-351.

17 David Ley, "Does Transnationalism Trump Immigrant Integration? Evidence from Canada's Links with East Asia," Journal of Ethnic and Migration Studies 39, no. 6 (2013): 921-938.

18 Johanna L. Walter, “Immigration, Transnationalism and 'Flexible Citizenship' in Canada: An Examination of Ong's Thesis Ten Years On," Tijdschrift voor Economische en Sociale Geografie, 100, no. 5 (2009): 635-645.

19 Janet W. Salaff and Arent Greve, “Can Women's Social Networks Migrate?” Women's Studies International Forum 27, no. 2 (2004): 149-162. 
to maintain their class status in the host society. ${ }^{20,}{ }^{21}$ Despite their agency and creativity, like other immigrants with minoritized backgrounds, under- and un-employment remained a persistent challenge for study participants. Given this situation, immigrants may start returning to China or circulating between China and Canada. ${ }^{22}$ Guo conceives return migrants as double diaspora (i.e., diaspora in relation to both Canada and China and simultaneously diasporas and returnees). ${ }^{23}$ His study uncovers a range of reasons immigrants move to Canada in the first place, and later on, return to China. In his study, $75 \%$ of the respondents reported that they were economically better off in China than in Canada. Nevertheless, close to half of the respondents still maintained their family ties to and/or signaled desires for lives in Canada. Ho and Ley's study touches on another layer of complexity for immigrant returnees. ${ }^{24}$ They refer to skilled Chinese immigrants who return to China as "middling" immigrants, arguing that as these immigrants experience downward social mobility in Canada, they are not typically the top talents that the Chinese government targets with preferential policies. As such, the social marginalization that the immigrant respondents experienced in Canada could be reproduced in China.

Clearly scholarship on Chinese transnationalism is expanding. However, researchers in this area do not necessarily agree on what transnationalism is. For instance, Ley uses transnationalism to refer to specific types of activities, such as maintaining contacts in home countries, travel, and sending economic remittance. ${ }^{25}$ Yang sees transnational movement as a mode of labor-market incorporation enabled through variations in cross-national markets which

20 Guida Man and Rina Cohen, eds., Engendering Transnational Voices: Studies in Family, Work, and Identity (Waterloo, Ontario: Wilfrid Laurier University Press, 2015).

21 Tania Das Gupta, Guida Man, Kiran Mirchandani and Roxana Ng, "Class Borders: Chinese and South Asian Canadian Professional Women Navigating the Labor Market," Asian and Pacific Migration Journal 23, no. 1 (2014): 55-83.

Philip Yang, "Transnationalism as a New Mode of Immigrant Labor Market Incorporation: Preliminary Evidence from Chinese Transnational Migrants," Journal of Chinese Overseas 2, no. 2 (2006): 173-192.

23 Shibao Guo, "From International Migration to Transnational Diaspora: Theorizing 'Double Diaspora' from the Experience of Chinese Canadians in Beijing," Journal of International Migration and Integration 17, no. 1 (2016): 153-171.

24 Elaine Lynn-Ee Ho and David Ley, "Middling' Chinese Returnees or Immigrants from Canada? The Ambiguity of Return Migration and Claims to Modernity," Asian Studies Review 38, no. 1 (2014): 36-52.

25 Ley, “Does Transnationalism Trump Immigrant Integration?" 921-938. 
afford different employment opportunities and rewards. ${ }^{26}$ Ong uses transnationalism to reference the "cultural logic" through which individuals respond opportunistically to the flexible regime of accumulation. ${ }^{27}$ Regardless of the approach to transnationalism, most studies follow the experiences of specific groups of individuals - largely business immigrants (capitalist class) or skilled immigrants (labor) - in order to understand the construction of the phenomenon of transnationalism. Although the existing studies address, or at least acknowledge, the conjunctions between capitalism and transnationalism, global capitalism is often taken as a context in which individuals respond with transnational engagements. Researchers have rarely attended to the process of global capitalization as it constitutes, and is constituted by, individuals' transnational engagements. This paper addresses this issue through resorting to the idea of transnational social field.

\section{Transnational Social Field: An Expanded Conceptual Framework}

The term transnational social field was first brought forward by Glick Schiller, Basch and Blanc-Szanton who define transnationalism as "the processes by which immigrants build social fields that link together their societies of origin and settlement." ${ }^{28}$ Their conceptualization of transnationalism is premised on six proposals. Taken together, these proposals can be summarized into the following. First, they believe that transnationalism is rooted in the daily experiences, social relationships, and identity work of migrants, who are compelled to work within the hegemonic contexts of the local and the global. Second, to study transnationalism, they challenge researchers to go beyond methodological nationalism, or the tendency to treat nation state as the boundaries for social analysis. ${ }^{29}$ Instead, they ask researchers to rework social science concepts to capture the fluid and complex experiences of immigrants. Third, they

26 Yang, "Transnationalism as a New Mode of Immigrant Labor Market Incorporation," 173-192.

27 Ong, Flexible Citizenship.

28 Nina Glick Schiller, Linda Basch and Cristina Blanc-Szanton, "Transnationalism: A New Analytic Framework for Understanding Migration," Annals of the New York Academy of Sciences 645, no. 1 (1992): 1 .

29 Peggy Levitt and Nina Glick Schiller, "Conceptualizing Simultaneity: A Transnational Social Field Perspective on Society," International Migration Review 38, no. 3 (2004): 1002-1039. 
also believe that the transnational migrant experience is inextricably linked to global capitalism and must be studied within that context.

Levitt and Glick Schiller continue developing the notion of transnational social field. Drawing on Bourdieu's work on social fields and the work by Manchester school on social networks, they define social field as "a set of multiple interlocking networks of social relationships through which ideas, practices, and resources are unequally exchanged, organized, and transformed." ${ }^{30}$ Informed by Bourdieu's work in particular, they propose that social fields are "created by the participants who are joined in struggle for social position," which can impose disruption as well as reinforce power relations along social differences such as gender, race, and class. ${ }^{31}$ Following the same line of thinking, Shan, Pullman and Zhao propose the notion of transnational social space. ${ }^{32}$ This idea of a transnational social space is not to replace the use of transnational social field. It is rather to suggest that some of the transnational fields are contingent and precarious. It is also to stress that different games of distinctions emanating from diverse social fields may be evoked to constitute the power matrixes shaping transnational engagements.

People similarly endowed with diverse capital or similarly situated within matrixes of power may not be equally active in the transnational field. To explain such differences, in their construction of transnational social field, Levitt and Glick Schiller also make a distinction between ways of being and ways of belonging. ${ }^{33}$ Ways of being refer to how individuals may be embedded within a transnational field but may not consciously identify with the field itself. Ways of belonging, on the other hand, reference actual social practices that signal a conscious connection and identification with particular field. Such a distinction highlights that a transnational social field is simultaneously an objective and subjective phenomenon that can be studied through an understanding of individual experiences. Further, transnational social relations and networks may be constituted through multiple institutions, organizations, and actors across place. I propose that the everyday experience of individuals is indeed socially organized across locality, although the organizational property of the transnational field might be more emergent than established. Levitt and Glick Schiller

$30 \quad$ Ibid., 1009.

$31 \quad$ Ibid., 1008.

32 Hongxia Shan, Ashley Pullman, and Qinghua Zhang "The Making of Transnational Social Space: Chinese Women Managing Careers and Life between China and Canada," Asian and Pacific Migration Journal 25, no. 2 (2016), 105-129.

Levitt and Schiller, "Conceptualizing Simultaneity," 1002-1039. 
touch on this point when they state that "social fields contain institutions, organizations and experiences [...] that generate categories of identity that are ascribed to or chosen by individuals and groups." ${ }^{34}$ By addressing how various types of actors act in concert to produce transnationalism, I also hope to trace how global capitalism or the global process of capitalization, with its crisisprone property, recruits compliance and gets constantly renewed in practice.

\section{The Research, Methods, and Participants}

This paper draws on a qualitative study that examines the social organization of the career trajectories for a group of transnational Chinese immigrant women. This study has two inter-related components that were completed between June 2014 and June 2015. The first part of the study involved lifehistory style interviews with 15 Chinese migrant women, who 1) were trained in applied sciences and engineering and 2) moved twice or more between China and Canada for work and settlement purposes. The women were recruited to participate in the research through three means of communication: 1) the personal and professional networks of the research team, 2) advertising the study through posting flyers in community centers, and 3) using Chinese social media such as QQ and WeChat. Table one provides the demographic information of the women. Of the 15 women, 12 were in their 30s and 40s, two above 50 and one in her 20s. All but two were married and had at least one child, while one was single and the other divorced. All women were trained in what is traditionally known in China as li-gong-ke or applied sciences and engineering (seven in architecture and engineering, three in computer sciences, one in mathematics, one in medical sciences, one in husbandry, and two in a mix of sciences and social sciences). Prior to migrating to Canada, one earned a doctoral degree (Hong), five a master's degree (Anna, Biella, Emily, Cindy, Gina, and Nancy), and eight a bachelor's degree (Deng, Fang, Irene, Julia, Kate, Linda, Mandy, and Oprah). The majority of the women immigrated to Canada as skilled immigrants (dependent or independent). Linda and Emily were the exception: Linda migrated as a business migrant, and Emily came as a dependent of her parents who were business migrants. The first landing in Canada for all women occurred between 1996 and 2012.

Interviews with the women were conducted in Chinese mixed with English, either face-to-face, virtually through Skype, or over the phone. Interviews

Ibid., 1010. 
TABLE 1 Transnational and occupation mobility of study participants

\begin{tabular}{|c|c|c|c|c|}
\hline Name & $\begin{array}{l}\text { Last occupation before } \\
\text { immigrating to } \\
\text { Canada }\end{array}$ & $\begin{array}{l}\text { First occupation } \\
\text { after arrival in } \\
\text { Canada }\end{array}$ & $\begin{array}{l}\text { Last/current } \\
\text { occupation in } \\
\text { Canada }\end{array}$ & $\begin{array}{l}\text { Location at time } \\
\text { of interview }\end{array}$ \\
\hline Anna & $\begin{array}{l}\text { Space planner } \\
\text { in international } \\
\text { company }\end{array}$ & $\begin{array}{l}\text { Professional } \\
\text { assistant to a } \\
\text { builder }\end{array}$ & $\begin{array}{l}\text { Coordinator for a } \\
\text { family builder (on } \\
\text { maternity leave at } \\
\text { time of interview) }\end{array}$ & Canada \\
\hline Biella & $\begin{array}{l}\text { Owner of an } \\
\text { engineering } \\
\text { company and } \\
\text { daycare center } \\
\text { (maintaining } \\
\text { company and } \\
\text { daycare center after } \\
\text { immigrating to } \\
\text { Canada) }\end{array}$ & $\begin{array}{l}\text { Registered an } \\
\text { educational } \\
\text { company } \\
\text { (exploring } \\
\text { the direction } \\
\text { of business at } \\
\text { the time of the } \\
\text { study); }\end{array}$ & $\begin{array}{l}\text { Owner of an } \\
\text { educational } \\
\text { company }\end{array}$ & $\begin{array}{l}\text { Canada (NOTE: } \\
\text { Moved every few } \\
\text { months between } \\
\text { Canada and } \\
\text { PRC-4×) }\end{array}$ \\
\hline Cindy & $\begin{array}{l}\text { Instructor, } \\
\text { coordinator and } \\
\text { supervisor at an } \\
\text { airline company. }\end{array}$ & $\begin{array}{l}\text { Coordinator at } \\
\text { an investment } \\
\text { company }\end{array}$ & $\begin{array}{l}\text { Coordinator at } \\
\text { an investment } \\
\text { company (on } \\
\text { maternity leave at } \\
\text { time of interview) }\end{array}$ & $\begin{array}{l}\text { Canada (NOTE: } \\
\text { Moved every } \\
\text { few months } \\
\text { between } \\
\text { Canada and } \\
\text { PRC) }\end{array}$ \\
\hline Deng & $\begin{array}{l}\text { Sales and marketing } \\
\text { manager at an } \\
\text { international } \\
\text { company }\end{array}$ & Programmer & Real estate agent & Canada \\
\hline Emily & $\begin{array}{l}\text { Teacher at an } \\
\text { international school }\end{array}$ & Part-time tutor & Part-time tutor & $\begin{array}{l}\text { Canada (NOTE: } \\
\text { Moved between } \\
\text { Canada and } \\
P R C-6 \times)\end{array}$ \\
\hline Fang & Business owner & $\begin{array}{l}\text { Took care of own } \\
\text { kids }\end{array}$ & $\begin{array}{l}\text { Took care of own } \\
\text { kids }\end{array}$ & PRC \\
\hline Gina & IT sales person & $\begin{array}{l}\text { Clerk at a } \\
\text { Chinese radio } \\
\text { company }\end{array}$ & $\begin{array}{l}\text { Owner of } \\
\text { immigration } \\
\text { consulting } \\
\text { services company }\end{array}$ & Canada \\
\hline
\end{tabular}




\begin{tabular}{|c|c|c|c|c|}
\hline Name & $\begin{array}{l}\text { Last occupation before } \\
\text { immigrating to } \\
\text { Canada }\end{array}$ & $\begin{array}{l}\text { First occupation } \\
\text { after arrival in } \\
\text { Canada }\end{array}$ & $\begin{array}{l}\text { Last/current } \\
\text { occupation in } \\
\text { Canada }\end{array}$ & $\begin{array}{l}\text { Location at time } \\
\text { of interview }\end{array}$ \\
\hline Hong & Medical doctor & $\begin{array}{l}\text { Postdoctoral } \\
\text { researcher }\end{array}$ & $\begin{array}{l}\text { Postdoctoral } \\
\text { researcher }\end{array}$ & PRC \\
\hline Irene & Engineer & $\begin{array}{l}\text { Drafter in an } \\
\text { engineering } \\
\text { company }\end{array}$ & $\begin{array}{l}\text { Senior web } \\
\text { master and } \\
\text { project manager }\end{array}$ & Canada \\
\hline Julia & $\begin{array}{l}\text { Registered engineer } \\
\text { for a construction } \\
\text { company }\end{array}$ & $\begin{array}{l}\text { Owner of } \\
\text { immigration } \\
\text { consulting } \\
\text { company }\end{array}$ & $\begin{array}{l}\text { Owner of } \\
\text { immigration } \\
\text { consulting } \\
\text { company }\end{array}$ & $\begin{array}{l}\text { Canada (NOTE: } \\
\text { Stayed a few } \\
\text { months in both } \\
\text { Canada and } \\
\text { PRC) }\end{array}$ \\
\hline Kate & $\begin{array}{l}\text { Worker at a state- } \\
\text { owned company in } \\
\text { rural development }\end{array}$ & $\begin{array}{l}\text { Waitress and } \\
\text { cook }\end{array}$ & Tutor & $\begin{array}{l}\text { Canada (NOTE: } \\
\text { Moved between } \\
\text { Canada and } \\
\text { PRC every few } \\
\text { months- } 5 \times)\end{array}$ \\
\hline Linda & $\begin{array}{l}\text { Owner of after- } \\
\text { school center }\end{array}$ & $\begin{array}{l}\text { Owner of } \\
\text { daycare center }\end{array}$ & $\begin{array}{l}\text { Owner of daycare } \\
\text { center }\end{array}$ & Canada \\
\hline Mandy & $\begin{array}{l}\text { Government } \\
\text { employee at a hydro } \\
\text { company }\end{array}$ & $\begin{array}{l}\text { Cashier and } \\
\text { assistant cook }\end{array}$ & $\begin{array}{l}\text { Cashier and } \\
\text { assistant cook }\end{array}$ & Canada \\
\hline Nancy & $\begin{array}{l}\text { Government } \\
\text { employee in } \\
\text { civil aviation } \\
\text { administration }\end{array}$ & Part-time cashier & Part-time cashier & Canada \\
\hline Oprah & Topographer & $\begin{array}{l}\text { Defined herself } \\
\text { as a "housewife; } \\
\text { volunteers on a } \\
\text { farm }\end{array}$ & Looking for a job & Canada \\
\hline
\end{tabular}


ranged from 45 minutes to two hours. Face-to-face interviews were conducted in my office or a place convenient for the participants. Interviews focused on their migratory and career trajectories. Particular attention was paid to how the women sought out or responded to opportunities, and how they imagined, justified, planned, and realized their migratory and career moves in relation to the social, cultural, familial, and economic contexts within which they negotiated their social positionality and professional opportunities. All interviews were transcribed verbatim in the language of the interviews and sent back to the women for member check. Where the women requested revision of original transcripts, we accepted the revised version as the basis for data analysis. Interviewer reflection was conducted after each interview to generate initial and emerging themes, as well as to identify the actors that play an important role in the constitution of the transnational field the women found themselves.

Interviews with the women pointed to three interrelated areas that influenced the women's transnational experiences: the public (educational and governmental), private (corporate), and community-based organizational policies and/or practices related to the recruitment and retention of immigrant women in sciences and engineering in both China and Canada. To learn about the public policies and practices, interviews were conducted with one sectoral researcher, one immigration consultant, three immigrant service workers, two educators and one staff member in a higher education institution in Canada, and one group of government officials (four people) from China who were on a trip to recruit overseas talents from Vancouver. To develop a sense of the policies and practices in the corporate world, interviews were conducted with one human resource manager and two head hunters (in one interview) in Canada, one manager of a private funding organization, and one Chinese entrepreneur who operated a private foundation and was starting a large business in Canada. In the community realm, interviews were conducted with three advocates for women professionals in Canada, and one Chinese leader from a professional Chinese association in Canada. A manager from an association for overseas professional women scientists in China decided to respond to our questions in writing, rather than taking an interview. In addition to these interviews, government documents, such as immigration policies in Canada and overseas talent recruitment policies in China, were collected in order to provide a policy context for the study.

All interviews from the second part of the study were also transcribed verbatim and sent back to the participants for member check. Concerted efforts of data analysis took place right after completion of data collection. Interviews with the women were analyzed thematically to track their transnational career trajectories and strategies. Data generated from the second part of the study 
were analyzed to identify the actors and factors that pushed and pulled the Chinese women in different directions. A closer examination of both sets of data shows how a complex of transnational social relations are reticulated as a multitude of actors, policies, and practices come into interactions vis-à-vis global capitalism. It is this net/work of actors, policies, and practices on which the rest of this paper focuses upon.

\section{Immigrant Women's Migratory and Career Trajectories}

The Chinese women who participated in the study immigrated to Canada for various reasons. Some of them were career related: institutional and administrative constraints encountered at work, income penalty for being a Chinese working in international companies, and/or limited international mobility due to holding Chinese passports. The majority of the women also suggested that their migratory decisions were, in part, the result of family influence or familial decisions (i.e., spouse's or parents' decisions, the need to have a second child, and/or the need to provide a more relaxed educational environment for children). Some also related that they were attracted to Canada because of the quality life, highlighting food safety, air quality, the natural environment, and, in one case, the Western style of life. They chose Vancouver as the place of landing primarily because of its geographical proximity to China, and, in some cases, due to family ties and connections with friends who were already living in Vancouver. Between three weeks to four years after arriving, 14 women returned to China and one moved to New Zealand (to close her daycare business there). Although the circumstances for their return migration differed from case to case, they could be summarized under three headings: 1) dismal employment prospects in Canada; 2) perceived career and business opportunities in China given the booming economy (see also Guo);35 and 3) uniting families and caring for elders. At the time of the interviews, however, only two women were still working in China and all other participants had migrated back to Vancouver, reportedly for reasons related to their children's education. When asked about their future migratory plan, the majority of the women were ambivalent or equivocal about where to settle in the future. Indeed, it was clear from the data that the women's transnational movements were interlinked with their overall family plans and relations, as well as the economic opportunities presented to them or perceived across place.

35 Guo, “From International Migration to Transnational Diaspora," 153-171. 
With regard to their career lives, at the time of the study, six of the women were still in a state of transience, working in non-standard employment positions, such as tutors, or were unemployed and/or preparing to return to university or college. Four women managed to acquire paid employment in professional fields. Among them, two remained in their original fields of training, one (Hong) by returning to China to become a medical professor and one (Irene) by switching to a neighboring field and becoming the only woman who made it to a managerial position in a mainstream company in Canada. Two switched their specialties: Anna, an interior design architect, became a housing project coordinator, and Cindy became a coordinator for a Chinese investment company. Five of the women (re)started their own businesses or became self-employed. Biella and Linda owned businesses prior to coming to Canada and continued on this track after arrival. Three others (Deng, Gina, and Julia) became self-employed with their businesses either straddling China and Canada or remaining tightly anchored to the Chinese community in Canada; Deng became a real estate consultant, while Gina and Julia opened immigration and education consultancy companies in Canada that exclusively served Chinese clientele. Julia described her business in the following way:

What I do is to communicate with people [...] the information that you know [here in Canada] to people who need the information. Our clients are those who trust me, because they came through my social network and sought me out. [... Meanwhile,] you need to understand the most updated immigration policies here [in Canada].

In this case, Julia requested that a staff member write exams to be qualified as an immigration consultant in Canada. Meanwhile, she also transformed her previous social capital from China into business opportunities in Canada. To a great extent, she made her career possible through bringing together cultural capital, social networks, and economic capital (investment by friends) across place.

The case above clearly shows that many of the women were extremely entrepreneurial. They were aware of their unique positions within the transnational space and made strategic decisions to capitalize on their transnational positionalities. However, what needs to be noted is that identification of their transnational advantage did not always translate into individual success. For instance, when Deng lost her job as a computer program developer in Vancouver, she spent time developing a type of management software and tried to sell it to the hospitality industry in China. She expressed that she had 
an extensive social network within the hospitality industry in China. She, however, discovered that China was still reliant on intensive labor and not ready for a technology-based management system. Although she ultimately failed in this endeavor, her experience highlights that when constructing their career pathways, the women were imaginative, adventurous, and entrepreneurial. Importantly, they were sensitized to their transnational positionality and attempted to leverage it as a comparative advantage, although there was no safety net for such entrepreneurial endeavors.

Also of note, the majority of the participants ended up working for Chinese owners and investors and/or serving the Chinese communities either in Canada or in China. In fact, out of all the women who participated in the study, only Irene located a position within a graphic design company owned by Canadians. The research finds that working for Chinese employers often resulted in a clash between prior class positions (i.e., professional middle class) that participants subjectively identified with and the class position (i.e., working class) that they were reduced to after immigration. For instance, Anna, trained in interior architecture in the United Kingdom, was a space planner in Beijing. After moving to Canada, she worked initially for a Chinese builder as a consultant before moving on to work as a housing project coordinator for a Chinese family who resided outside of Vancouver. Deep at heart, however, she felt little respect for her former employer who she referred to as "Shanxi Farmer" as he was perceived as unskilled except for a keen sense for money. Regardless of how the women reconciled their new realities, the trend for the women to concentrate within the Chinese business world constitutes the problematic I wish to investigate further below.

\section{Production of the Transnational Field: The Governments}

As suggested in the last section, the Chinese women often found themselves engaged within the Chinese business world. This business world should be understood as different from ethnic enclave businesses. It is also drastically different from the kind of Mandarin capitalism or Confucian capitalism that Ong describes in South Asia; that is, a form of capitalism based primarily on fraternity networks. ${ }^{36}$ The type of business practices that the research participants engaged in signal distinct ways global capitalism is accomplished today in the Asian Pacific rim, which produces possible transnational engagements for the women. In the following two sections, I examine a multitude

$36 \quad$ Ong, Flexible Citizenship. 
of institutions as they conjoin labor and capital in order to understand the organization of the transnational social field. In the current section, attention is paid to how governments on both sides have mobilized particular kinds of mobility in the competition for human and economic resources.

\section{Canadian Governments Appealing to the Skilled and the Entrepreneurial}

Vancouver is an urban city within British Columbia (BC), a province in Western Canada. The city is uniquely situated in the social, cultural, economic and geographical landscape of the Asian Pacific rim and is perhaps better known in the world for its exorbitant real estate market. In Global China and the Making of Vancouver's Residential Property Market, David Ley delineates the global political economy besieging Vancouver from a historical perspective. ${ }^{37}$ Ley points out that $\mathrm{BC}$ was perhaps hit the hardest during the economic recession following the 1970s. In response, the provincial government launched a series of market-oriented reforms to revitalize the local economy based on an entrepreneurial agenda. As Canadians faced economic stagnation and cyclical recessions, Asia witnessed the economic rise of Hong Kong, Singapore, South Korea, and Taiwan, and more recently China and India. Canadian provincial and federal governments saw the economic growth in the Asia Pacific region and undertook repeated trade missions to Asia to enhance trade, capital flows, and immigration in the region.

Skilled immigration in Canada has been in effect since the 1960s in order to attract immigrants with educational and professional backgrounds to fuel the economy. Business immigration as a stream initially broke from the skilled immigrant category in 1978 to allow individuals holding a significant amount of economic capital and entrepreneurial experience to come to Canada. This entrepreneurial stream has been reconfigured over the years, but the basic requirement is for an immigrant to establish a business in Canada and employ at least one Canadian. The investor stream was established in 1986 initially to attract wealthy people from Hong Kong who were apprehensive about Hong Kong's return to China. To come to Canada under the investor class, an immigrant is required to commit a large amount of capital that is returnable, without interest, after five years. Canada has been extremely successful in attracting business immigrants. ${ }^{38,39}$ The profile of business immigrants has been domi-

\footnotetext{
37 David Ley, "Global China and the Making of Vancouver's Residential Property Market," International Journal of Housing Policy (2015): 1-20.

38 Ibid.

39 Wong, "Globalization and Transnational Migration," 329-351.
} 
nated by Greater China, initially by people from Hong Kong and Taiwan, and now individuals from Mainland China. Business immigrants, particularly rich investors, tend to land in —or relocate after initial landing — BC and Vancouver in particular. This political and economic context means that there is a large sum of, what some of my research participants referred to as, "surplus capital" or "loose money" looking for opportunities of capitalization.

\section{Appealing to Talented Chinese Diaspora: Roles of the Chinese Governments}

China is relatively late in joining the global war for talents. When Canada started reconfiguring its immigration policies to target skilled workers in the 1960s and 1970s, China as a nation was in the throes of economic stagnation and the Cultural Revolution. It was not until 1976 that Deng Xiaoping, upon the ending of the Cultural Revolution, started reforming and liberalizing the national economy and opening up the country to the world. With the goal to build a socialist market economy, the Chinese government has increasingly incorporated "neoliberal elements interdigitated within authoritarian centralized control." ${ }^{40}$ For instance, state regulations surrounding labor mobility were historically rigid in China. However, as economic reform deepened, related regulations have become relaxed, especially for those who are highly educated.

When it comes to international migration, China has a tradition of sending students overseas for training and of using administrative mechanisms to bring overseas students back to serve the country. These mechanisms, however, were severely compromised after the June 4th Incident in 1989, when countries such as the United States and Canada granted permanent residence to Chinese students who were believed to have suffered from political oppression. This loss of talents to the West led Deng Xiaoping to call for the return of its overseas diaspora, during his 1991 trip to South China, regardless of their ideological differences. ${ }^{41}$ This call marked the commencement of the country's concerted efforts to bring back Chinese trained overseas, casting return migration as a nonpolitical and non-ideological choice and a technical solution to the development problems facing the country. $42,43,44$

\footnotetext{
$40 \quad$ Harvey, The Condition of Postmodernity, 128.

41 David Zweig, Changgui Chen and Stanley Rosen, "Globalization and Transnational Human Capital: Overseas and Returnee Scholars to China," The China Quarterly 179 (2004): 735-757.

42 Ibid.

43 Ong, Neoliberalism as Exception.

44 Author, forthcoming.
} 
This study points out that China has ratcheted up its efforts to mobilize its overseas diaspora so that they contribute their skills and knowledge to the development of the country. This becomes evident in the discourse used during a promotional trip of a group of Chinese city-level government officials in Vancouver. Below are some of the notes taken about the event:

The promotional event was well attended by around 30 people, some Chinese students, some community leaders, and some academicsthe majority of them were Chinese but there were also a few Caucasian Canadians present. The government officials introduced their policies and provisions for top talents from abroad. Contrary to the stereotypical image of a serious and dull statesman, the leader of the team was a humorous, witty, and a well-spoken public figure. He delivered a wellpaced speech-informational and inspiring. In the PowerPoint that he presented, he showed characteristic scenery of the city. When he cited a poem by a well-known poet who was born in this area, many people in the audience recited with him.

An elegant reception followed the information session after which the officials allowed time for my interview. During the interview, they shared that their talent recruitment plan ran parallel to the flagship talent recruitment and retention plan of the central government. This plan provides generous funding and training for Chinese overseas who have received degrees from abroad in order to turn their skills and knowledge into business enterprises. The government officials revealed that their recruitment plan gives preference to those with special expertise in applied sciences and technology. They also stressed that training is provided to the returning experts to equip them with entrepreneurial knowledge in China.

\section{Public, Private, and Community Organizations Enlisted in the Transnational Field}

If the nation-based competition for talent generates transnational mobility, it takes a host of institutions-including those that are public, private, or community-based - to make it possible for immigrants to engage in transnational career lives. Some of the institutions and organizations are consciously involved while others are enlisted as aids to transnational movement. In Canada, various types of immigrant services and organizations are involved in settling and integrating immigrants to the host labor market. They are not necessarily designed to encourage immigrants' transnational mobility. For instance, the majority of the immigrant interviewees in the study invested in 
gaining Canadian credentials and certificates (for example, to become an immigrant consultant or real estate agent) as forms of cultural capital and some of them also tried to leverage such cultural capital in the transnational field. This very phenomenon demonstrates that in the transnational field, cultural capital gained in Canada command, in general, more power. This cultural order is certainly reaffirmed in China's talent recruitment policies that center degrees from the West. ${ }^{45}$ Further, in some of the overseas talent recruitment practices discussed below, it should be noted that the actors-both private and public organizations - were based in Canada but held important ties to China.

Chinese diaspora community organizations play a role in wedding skills of the overseas Chinese with Chinese capital. A leader from a society for overseas Chinese students and professionals shared:

We are a not-for-profit organization registered in Vancouver. The mission of our society is to provide an exchange platform (for) Chinese in Vancouver who are with great project ideas but who do not have the platform to materialize these ideas.

This society is indeed a platform for skilled professionals to find the market for their skills and knowledge by matching the Chinese immigrants with potential investors. Located in Vancouver, the president of the society highlighted its resourcefulness:

Our society can provide some resources. What are these resources? Like the entrepreneurial competition that we held this year, it is to provide an opportunity for capital, skills and the market to join hands. We have been through various activities like this, which helped us accumulate social networks, especially when it comes to economic capital [...]. There are floats of financial capital that awaits good projects. Investors are looking for appropriate projects. You know that this is Vancouver, with a good number of business immigrants. That is, we are blessed with plentiful economic capital. The investors are also looking for a channel or a platform for the money to enter the market for further capitalization.

The society is not only involved in matching people and capital in Vancouver, it also plays a similar role in China:

45 Yanxian Mo, "Top Overseas Talent as a Distinguished Social Group: A Policy Study Using Critical Discourse Analysis," University of British Columbia: Master's Thesis. 2015. 
Quite a chunk of our time is spent receiving/meeting representatives from China. These representatives come all the way to look for high-end talents. We have the resources. Sometimes, there are events organized in China. [...] In August, the Beijing Centre for Overseas Chinese Students — with which we have close relationship_organized an activity called "Trip to Beijing by the Patriotic from the Overseas." We sent a team of five or six people over. One of them is in biomedicine, who was looking for collaborative opportunities. After that trip, she established some connections. [...] In cases like this, we try our best to assist them, including assisting them with funding application.

In addition to the Chinese government and diaspora community organizations, private foundations and organizations are also found to be active in the shaping of the transnational field. For instance, a manager from a private skill sourcing company introduced the company this way:

Our company is committed to building sciences and technology parks. We have developed seven parks in Beijing and Shenzhen [...] four parks in the United States [...] one in Canada, and one in Germany. Our main goal is to internationalize the management and operation of high-tech parks. On the one hand we cultivate enterprises. On the other hand, we try to eliminate time between borders [...] For instance, what I do in Canada is to effectively bring together innovations from both China and Canada, the Chinese and Canadian markets, and Chinese as well as Canadian capitals so as to speed up the process for enterprises to find larger market, larger finance capitals, and bigger innovations across borders. This is how we help them grow.

The manager continued to explain that what the company does is to connect innovations with the "two M's" (Market and Money) across borders. Of note, private skill sourcing companies do not work independently. Rather, they work closely with both Chinese and Canadian governments. For example, the interviewee highlighted:

We are merely a private organization. What we do, however, needs support from governments. For instance, support from the Ministry of Science and Technologies, and the Ministry of Commerce from China, and Innovation, Science and Economic Development Canada. [...] But their support is mainly around resources allocation, rather than as shareholder of the company. 


\section{Global Capitalists Joining Labor and Capital}

Finally, to fully understand the constitution of the transnational field, it is important to highlight some of the stories in which global capitalists from China combined labor and capital in practice. A report by the Mercator Institute for China Studies and Rhodium Group claimed that "We are entering a new era of Chinese capital." ${ }^{\text {"6 }}$ It projects that China is to triple its global assets from currently $\$ 6.4$ trillion us dollars to almost $\$ 20$ trillion by 2020 . According to Human Resources and Skills Development Canada, in 2012, China was Canada's second largest trading partner, after only the United States, and was its ninth largest source of foreign direct investment. ${ }^{47}$ Additionally, business immigrant investors and entrepreneurs, predominately Chinese by origin, bring a significant amount of investment capital to the country. 48

By referring to various surveys and economic statistics, Ley points out that residential property is a major investment interest to business immigrants in Vancouver, particularly those from Greater China. ${ }^{49}$ Indeed, in this study two women were involved in the real estate and housing construction industries. However, of the five women who embarked on entrepreneurial trajectories, four were also active in education and/or immigration. The Chinese woman investor interviewed was interested in building a financial center in Vancouver. A close examination of the entrepreneurial engagements of the women shows that the women were entrepreneurial and sensitive to transnational opportunities presented by global capitalists. Yet, their entrepreneurial moves were sometimes in response to crevices, if not crisis, in the lifeworld as well. The account of the woman investor we interviewed demonstrates both clearly:

[This is a city] for the wealthy to congregate. But they have not taken out their money. Why? There is no industry for them to invest in. [...] There is no driver industry. What we are seeing is a massive waste of human talents. There are close to 35,000 international students here in Vancouver alone. They know English. They know Chinese. They've learned advanced technology. They've developed finance and business knowledge and mind. But once they graduate, they are unemployed [...] They are desperate enough to become dishwashers [...] I discussed my investment

46 Thilo Hanemann and Mikko Huotari, Chinese FDI in Europe and Germany: Preparing for a New Era of Chinese Capital (Berlin: Mercator Institute for China Studies, 2015), 5.

47 Human Resources and Skills Development Canada (HRSDC), China and Canada: Economic Linkages, Migration and the Canadian Labour market (Ottawa: HRSDC, 2012).

48 Ley, "Global China."

49 Ibid. 
plan with the investment bureau in BC. They told me that they were deeply moved by my plan. The head said: "To be honest, this cannot be better timing." He said: "We just finished a meeting. A new policy is to be implemented. As long as you work in financing, we would give you tax deduction and exemption for five years."

The woman investor was herself a mother of an international student in Vancouver. She had her own businesses in China, but ventured into Vancouver. Setting up a financing center is not the only goal that she had. She also planned to build a residence for international students, hiring as staff members mothers who are here alone in Vancouver accompanying their children. Although we do not know whether her plan transpired, what can be noted is that as a business investor herself, she identified not only the availability of surplus capital floating in the market in Vancouver, but also the existence of a large labor pool as a result of immigration and labor market exclusion. The investor was ingenious in seeking ways to conjoin free flowing capital and idle labor.

Although the investor felt existing policy was supportive for her ambition, it was not clear at the time of the interview what lay ahead for her. The Mercator Institute report was drafted not to celebrate China as an economic driver: it rather aimed to encourage improvement of investment governance. This mix of policy and experience highlights that while Chinese capital brings economic opportunity, it also leads to cultural vigilance and social anxiety in the West vis-à-vis capital flows from China. ${ }^{50}$

\section{Troubling the Elite Façade of the Transnational Social Field: Discussion and Conclusion}

Chinese transnationalism is an expanding phenomenon. To understand its constitution, it is necessary to approach it as being generated as part and parcel of global capitalism. This paper takes on this challenge by tracing the migratory and career pathways of some professional Chinese immigrant women and a multitude of actors, including not only the government, but also public and private institutions and community-based organizations that participate in joining skilled labor and economic or monetary capital floating in the Asian Pacific area. The study might have provided anecdotal evidence on surplus capitals from China trotting the world. Global studies, however, have unequivocally pointed to the rising economic power of China in the global

Hanemann and Huotari, Chinese FDI in Europe and Germany. 
arena. ${ }^{51}$ It is likely this very economic context that makes Chinese transnational engagements a common practice for many. This large economic narrative, however, has to be read in conjunction with the contradictions and crises that people experience in their everyday world. In other words, despite its elitist façade, it should be noted that the transnational social field itself is fragile, contradictory, and prone to crises.

Global Chinese capitalism can be considered as a modernist project of China as it ratchets up its game in the global arena. Although it celebrates entrepreneurial and skilled subjects, not every skill, and not every Chinese body overseas is the desired subject within the transnational field. Free-floating capital from China are often in quest of scientific and technological skills that are directly relevant to the development needs of national economies. Not every skilled Chinese can become the desired transnational subjects either. Those who have a better chance within the transnational social field are often those with foreign training, hence endowed with Western cultural capital (i.e., degrees from the West).

For those who fulfil the profile of transnational entrepreneurial subjects and venture into the transnational field, there might be a hefty social cost to pay. In this study, the women, particularly those who are more entrepreneurial, tend to live transnational family lives. In fact, all 15 women, except for one, lived transnational family lives for at least a period of time. They "chose" transnational family lives because their desired life space is often not their desired economic space. Although some of them seem to ride on the neoliberal $\mathrm{im} /$ migration policies in both China and Canada, flexible citizenship was not found to be a sustainable plan for the women. In fact, to maintain flexible citizenship, the women had to stay flexible with their career plans. Furthermore, long-distance relationships, in some cases, not only took a toll on the spousal relationship, but also on the relationship between parents and children. Some of the women who accompanied their children as single parents in Vancouver were visibly unhappy during the interviews. One chose to divorce and remarry because of the long-distance relationship. In one family, the children were distanced from their father and stopped communicating with him as a result of his long absence as well as cultural clashes when they started living together again. Although the transnational field presents an elite façade, just as capitalism itself that is full of contradictions and crisis, there may be deeper social crevices in the corresponding lifeworld that circular migrants have to face. 


\section{References Cited}

Benton, Gregor. "Chinese Transnationalism in Britain: A Longer History." Identities: Global Studies in Culture and Power 10, no. 3 (2003): 347-375. DoI: 10.1080/10702890390228900.

Das Gupta, Tania, Guida Man, Kiran Mirchandani and Roxana Ng. "Class Borders: Chinese and South Asian Canadian Professional Women Navigating the Labor Market." Asian and Pacific Migration Journal 23, no. 1 (2014): 55-83.

Glick Schiller, Nina, Linda Basch and Cristina Blanc-Szanton. "Transnationalism: A New Analytic Framework for Understanding Migration." Annals of the New York Academy of Sciences 645, no. 1 (1992): 1-24.

Guo, Shibao. "From International Migration to Transnational Diaspora: Theorizing 'Double Diaspora' from the Experience of Chinese Canadians in Beijing." Journal of International Migration and Integration 17, no. 1 (2016): 153-171.

Hanemann, Thilo and Mikko Huotari. Chinese FDI in Europe and Germany: Preparing for a New Era of Chinese Capital. Berlin: Mercator Institute for China Studies, 2015.

Harvey, David. The Condition of Postmodernity. Oxford: Blackwell, 1989.

Ho, Elaine Lynn-Ee and David Ley. "Middling' Chinese Returnees or Immigrants from Canada? The Ambiguity of Return Migration and Claims to Modernity." Asian Studies Review 38, no. 1 (2014): 36-52.

Human Resources and Skills Development Canada (HRSDC). China and Canada: Economic Linkages, Migration and the Canadian Labour Market. Ottawa: HRSDC, 2012.

Levitt, Peggy and Nina Glick Schiller. "Conceptualizing Simultaneity: A Transnational Social Field Perspective on Society." International Migration Review 38, no. 3 (2004): 1002-1039.

Ley, David. "Does Transnationalism Trump Immigrant Integration? Evidence from Canada's Links with East Asia." Journal of Ethnic and Migration Studies 39, no. 6 (2013): 921-938.

Ley, David. "Global China and the Making of Vancouver's Residential Property Market." International Journal of Housing Policy, (2015): 1-20. http://dx.doi.org/10.1080/ 14616718.2015.1119776.

Ley, David. "Transnationalism." In International Encyclopedia of Human Geography, edited by Rob Kitchin and Nigel Thrift, 388-393. Oxford: Elsevier, 2009.

Ma, Laurence J. C., and Carolyn L. Cartier. The Chinese Diaspora: Space, Place, Mobility, and Identity. Lanham: Rowman \& Littlefield, 2003.

Man, Guida. and Rina Cohen, eds. Engendering Transnational Voices: Studies in Family, Work, and Identity. Waterloo, Ontario: Wilfrid Laurier University Press, 2015.

Mo, Yanxian. "Top Overseas Talent as a Distinguished Social Group: A Policy Study Using Critical Discourse Analysis." University of British Columbia: Master's Thesis. 2015. 
Ong, Aihwa. "Neoliberalism as a Mobile Technology." Transactions of the Institute of British Geographers 32, no. 1 (2007): 3-8.

Ong, Aihwa. Neoliberalism as Exception: Mutations in Citizenship and Sovereignty. Durham: Duke University Press, 2006.

Ong, Aihwa. Flexible Citizenship: The Cultural Logics of Transnationality. Durham: Duke University Press, 1999.

Ross, Douglas E. Archaeology of Asian Transnationalism. Gainesville: University Press of Florida, 2013.

Salaff, Janet W., and Arent Greve. "Can Women's Social Networks Migrate?" Women's Studies International Forum 27, no. 2 (2004): 149-162.

Shan, Hongxia, Ashley Pullman, and Qinghua Zhao. "The Making of Transnational Social Space: Chinese Women Managing Careers and Life between China and Canada." Asian and Pacific Migration Journal 25, no. 2 (2016), 105-129.

Sklair, Leslie. Transnational Capitalist Class. Hoboken, New Jersey: John Wiley \& Sons, 2012.

Vertovec, Steven. "Migrant Transnationalism and Modes of Transformation." International Migration Review 38, no. 3 (2004): 970-1001.

Walter, Johannal. “Immigration, Transnationalism and 'Flexible Citizenship' in Canada: An Examination of Ong's Thesis Ten Years On." Tijdschrift voor Economische en Sociale Geografie 100, no. 5 (2009): 635-645.

Wong, Lloyd L. "Globalization and Transnational Migration A Study of Recent Chinese Capitalist Migration from the Asian Pacific to Canada." International Sociology 12, no. 3 (1997): 329-351.

Yang, Philip. "Transnationalism as a New Mode of Immigrant Labor Market Incorporation: Preliminary Evidence from Chinese Transnational Migrants." Journal of Chinese Overseas 2, no. 2 (2006): 173-192.

Zweig, David, Changgui Chen and Stanley Rosen. "Globalization and Transnational Human Capital: Overseas and Returnee Scholars to China." The China Quarterly 179, (2004): 735-757. 